\title{
Rheological Behavior of Lubricating Greases at High Temperatures
}

\author{
by
}

Shigeki KOMATSUZAKI

(Hitachi Research Laboratory, Hitachi Ltd., 4026 Kojimachi, Hitachi, Ibaraki-ken 319-12)

\begin{abstract}
The rheological behavior of lubricating greases was studied in the temperature range from room temperature to about $250^{\circ} \mathrm{C}$ by using a concentric cylinder-type viscometer, which is more convenient for measurements at high temperatures than the widely used ASTM viscometer of capillary type.

The following results were obtained:

(1) Lubricating greases exhibited the Ostwald flow; that is, the viscosity was independent of the rate of shear in both regions of extremely low shear rates and extremely high shear rates.

(2) The rate dependence of viscosity was observed within a rather narrow shear rate range at high temperatures.

(3) The relative viscosity of each soap-thickened grease started to decrease as the temperature was increased beyond a certain value. This behavior was attributable mainly to the rupture of structural linkage of thickener micells or to the rupture of micells themselves, judging from the observation of electron micrographs.
\end{abstract}

\section{高温における潤滑グリースのレオロジー}

\author{
小松 崎 茂 樹*
}

（原稿受理：1977年 7 月21日）

\section{1. 緒言}

潤滑グリース(以下グリースと略す)は，増ちょう剂(thickener) 之基油 (base oil) からなる。潤滑の主役は約80〜90\%を占める 基油で, 増ちょう剂は油中で網目構造を形成し外部に余分の油が 流失するのを防止する役割を果たす．グリースが軸受中で使用さ れるとき, 必ず流動を伴い, 流動時のグリースの性質は静的状熊 と著しく異なるととが多く，乙れまでもレオロジー的性質に関す る多くの報告がある.

最近, 電気絶縁材料の進歩に伴い電動機が小型化し, 軸受部の 温度が上昇するなど, 高温でグリースが使用される頻度も多くな りつつある。しかし，高温でのレオロジー的性質に関する研究は 比較的少なく, 多くの未知の部分を残している.よって本報では, 高温におけるグリースのレオロジー的性質を検討することを目的 とし, 二重円筒式回転粘度計を用い, 高温に扔けるグリースの流 動挙動について考察した結果について述べる.

\footnotetext{
* (株) 日立製作所日立研究所 茨城県日立市久慈町 4026
}

\section{2. 供 試 試 料}

本報でとり挙げたグリースをTable 1 に示した. №.1〜 6 は金 属せっけんを增ちょう剤としているが，№.7 は非せっけんを増ち ょう剂としている．№.1〜3のリチウムせっけん増ちょう剂にお いて、N №.1 はステアリン酸リチウム, №. 2〜 3 は 12 -ヒドロキシ ステアリン酸リチウムを用いている．後の考察に必要な基油動粘 度 $\nu_{0}(\mathrm{cSt})$ の温度特性および動粘度 $\nu_{0}(\mathrm{cSt})$ から粘度 $\eta_{0}($ poise $)$ への変換のための密度 (比容積)-温度特性を Fig. 1〜2 亿示した.

\section{3. 実 験}

\section{$3 \cdot 1$ 測 定 装 置}

測定には，Fig. 3 に示した外筒回転型の二重円筒式の回転粘度 計を用いた。グリースは不均質な物質であるため, 外筒回転時に 内筒が中心よりずれ，測定が困難になることが多い，そこで本報 では, Fig. 3 に示したように外筒の底面のくぼみに, 内筒の先端 をはめこんで中心の位置を保つように工夫した装置を用いた。 測定する際には, 外筒 $(22 \phi)$ と内筒 $(20 \phi \times 70)$ の間に, 試料を 
Table 1. Grease Samples

\begin{tabular}{|c|c|c|c|c|c|}
\hline \multirow{3}{*}{$\begin{array}{c}\text { Grease } \\
\text { No. }\end{array}$} & \multicolumn{2}{|l|}{ Thickener } & \multicolumn{3}{|c|}{ Base oil } \\
\hline & \multirow{2}{*}{ Type } & \multirow{2}{*}{$\begin{array}{l}\text { Content } \\
(\mathrm{wt} \%)\end{array}$} & \multirow{2}{*}{ Type } & \multicolumn{2}{|c|}{$\begin{array}{l}\text { Kinematic } \\
\text { viscosity }(\mathrm{cSt})\end{array}$} \\
\hline & & & & $37.8^{\circ} \mathrm{C}$ & $98.8^{\circ} \mathrm{C}$ \\
\hline 1 & Lithium soap ${ }^{a}$ & 14.5 & \multirow{7}{*}{$\begin{array}{c}\text { Mineral } \\
\text { oil }\end{array}$} & 106.9 & 10.9 \\
\hline 2 & Lithium soap ${ }^{b}$ & 9.6 & & 136.0 & 10.2 \\
\hline 3 & $\begin{array}{l}\text { Lithium soap }{ }^{b}+ \\
\text { polyethylene }\end{array}$ & 12.0 & & 360.8 & 18.8 \\
\hline 4 & Sodium soap ${ }^{c}$ & 12.2 & & 79.8 & 10.6 \\
\hline 5 & $\begin{array}{l}\text { Aluminium } \\
\text { soap }^{d}\end{array}$ & 8.3 & & 158.0 & 10.5 \\
\hline 6 & Calcium soape & 10.3 & & 12.4 & 2.7 \\
\hline 7 & $\begin{array}{l}\text { Sodium tere- } \\
\text { phtalamate }\end{array}$ & 13.2 & & 118.8 & 12.0 \\
\hline
\end{tabular}

$a$ Lithium stearate

$b$ Lithium 12-hydroxy stearate

$c$ Sodium stearate

$d$ Alminium stearate

$e$ Calcium stearate

$f \quad \mathrm{~N}$-octadecyl sodium terephtalamate

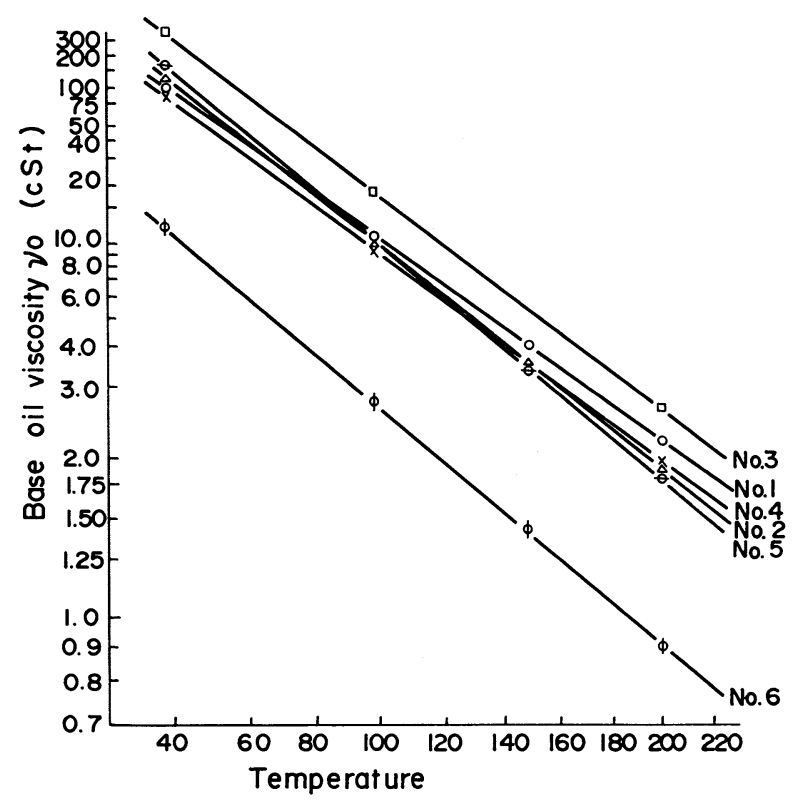

Fig. 1. Temprature dependence of the kinematic viscosity of base oils.

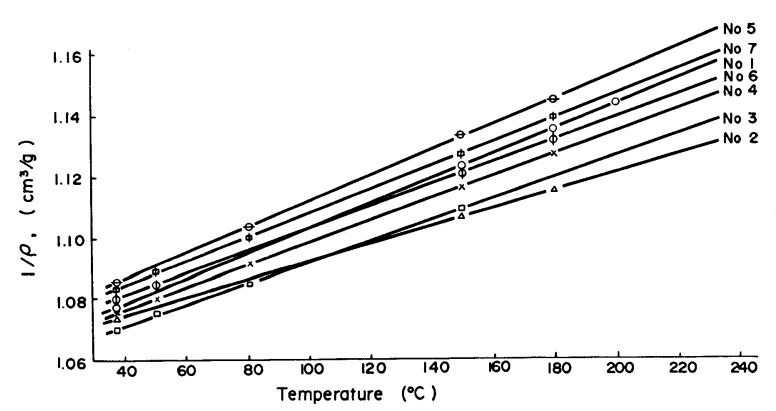

Fig. 2. Temprature dependence of the specific volume of base oils.
約 $12 \mathrm{ml}$ 充てんし外筒を回転させる.内筒に伝えられるトルクは， トーションワイヤーの㸚じれと釣り合う。トーションワイヤのね じれ角は, 差動トランス二次コイルの出力電圧に変換され, これ が記録計でペン書きされる。トーションワイヤーのねじれ角とね じれ定数から，粘性抵抗によるトルクが求まる.

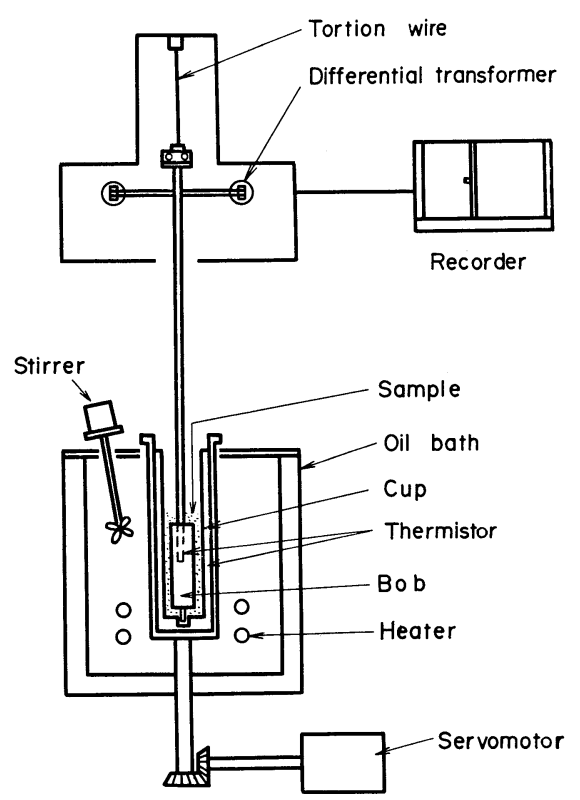

Fig. 3. Concentric cylinder-type viscometer.

$3 \cdot 2$ 測 定 法

グリースはチクソトロピックな性質を有し, 測定前の履歴によ って流動挙動が違ってくる.しかし, 測定を始める前にあらかじ め高せん断速度で十分回転させることによって再現性が得られる ようになる。

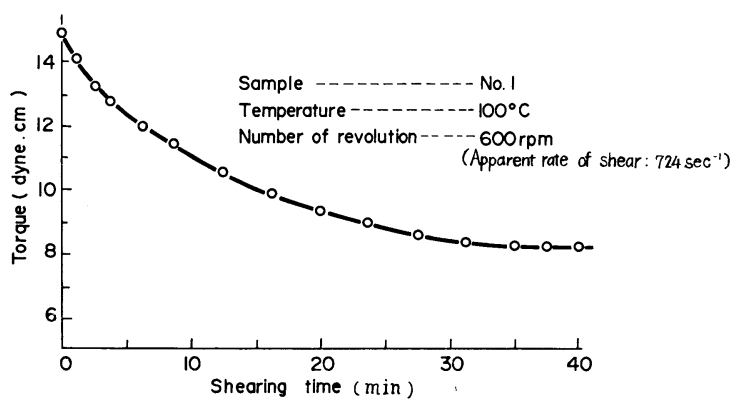

Fig. 4. Time dependence of torque.

グリースの粘度抵抗は, Fig. 4 亿示したようにせん断時間と之 屯に減少し，約30４0分経過後一定の值に落ちつく．とこでは， 600 rpmの回転数（見掛けのせん断速度 : $724 \mathrm{sec}^{-1}$ ) でせん断を与 え,トルクが一定になったのを確かめた後，漸次 500,400, 300 rpm と回転を下げながら，それぞれの回転数におけるトルクを測 定した。なお，600 rpmでせん断を与えた後，回転数を低い方か ら漸次上げながら同様の測定を行っても，同一のトルクが得られ るととを別途確認している。

\section{4. 結 果}

せ九断速度 $10^{-2} \sim 10^{2} \mathrm{sec}^{-1}$, 温度 $30 \sim 250^{\circ} \mathrm{C}$ の範囲で求めた見 


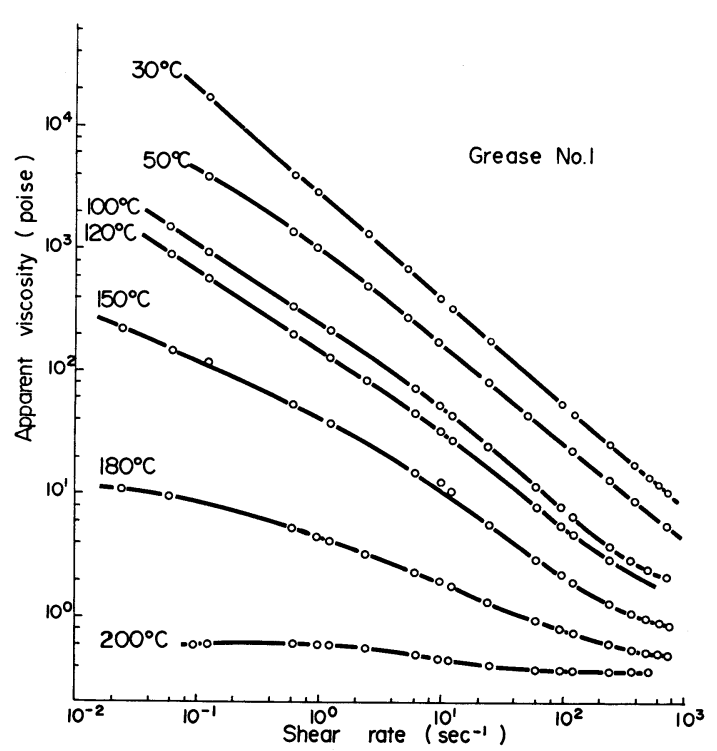

Fig. 5. Apparent viscosity versus shear rate curves for Grease No. 1.

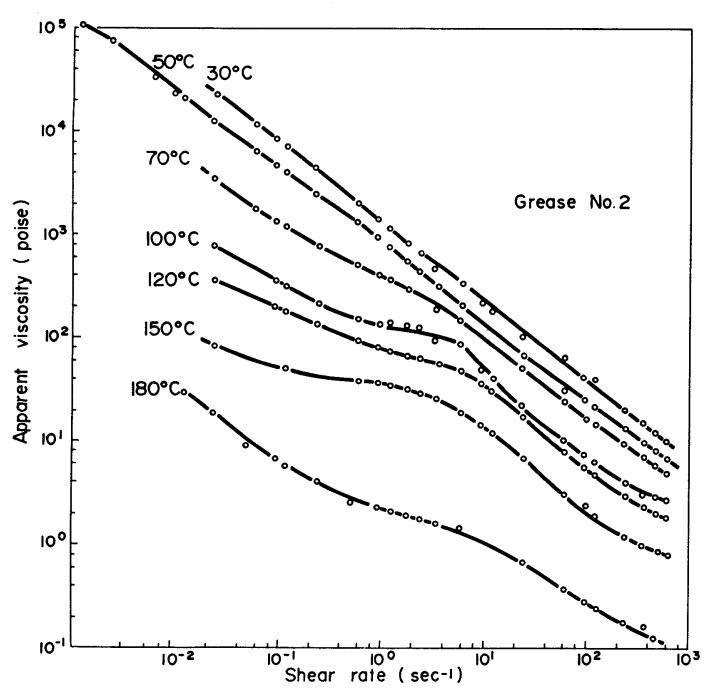

Fig. 6. Apparent viscosity versus shear rate curves for Grease No. 2.

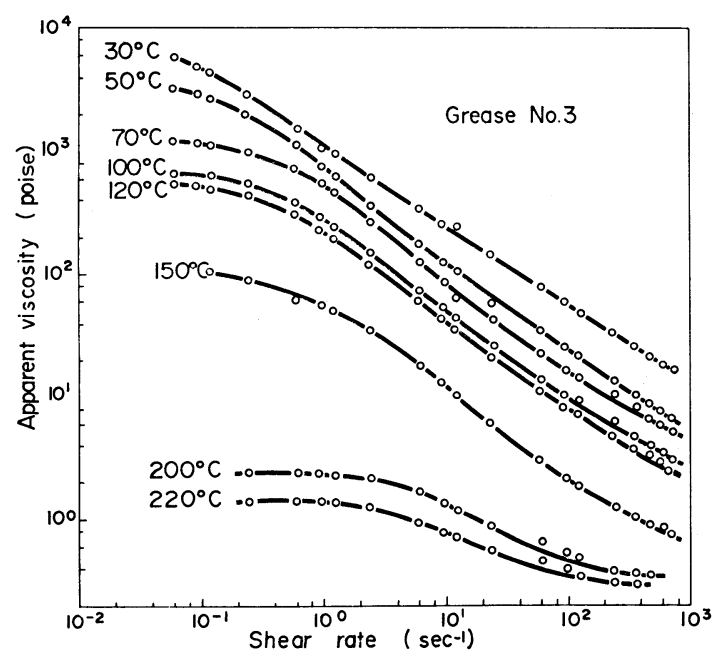

Fig. 7. Apparent viscosity versus shear rate curves for Grease No. 3.
掛け粘度はFig. 5〜11に示した. 各グリースの特徴を挙げると, 次のようである.

Fig. 5〜7 のグリースは，いずれあリチウムせっけんを増ちょ う剤あるいは增ちょう剤の一成分としている。乙れらのグリース は，30 $120^{\circ} \mathrm{C}$ までは温度の上昇ととあに見掛け粘度が徐々に低 下するが，150ㄷ 以上になると低下の仕方が大きくなっているて とから, この温度以上になるとリチウムせっけんの網目構造が熱 的に破壊されることが推察される.

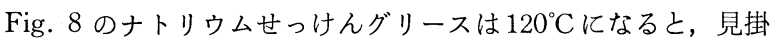
け粘度が著しく低下することから, この温度付近でナトリウムせ っけんの網目構造が 熱的破壊をうけることが推定される. しか し, $70^{\circ} \mathrm{C}$ における見掛け粘度が50 $50^{\circ}$ における值より高いという特 異な挙動む現れている.

Fig. 9 のアルミニウムせっけんグリースの挙動は極めて特異で ある. 200〜 $250^{\circ} \mathrm{C}$ 付近ではほぼニュートン流動に近いが，100〜

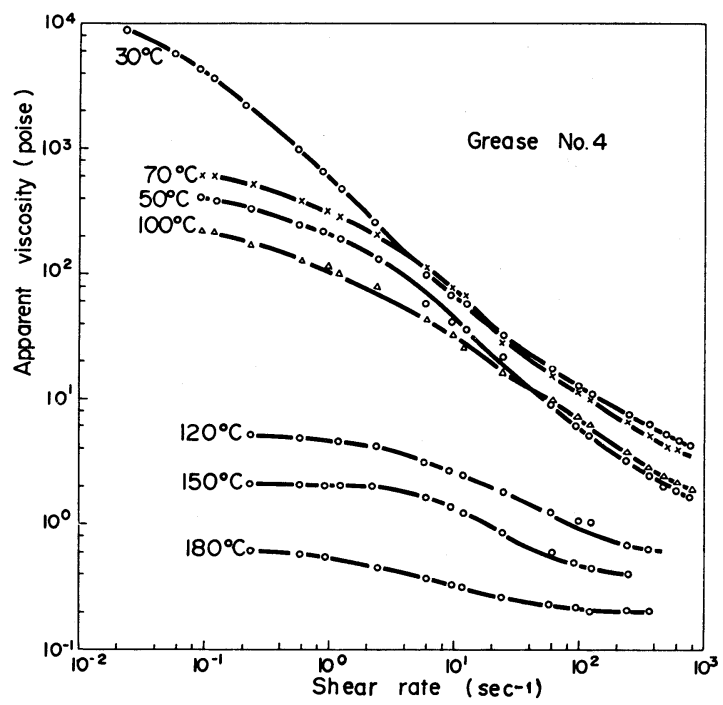

Fig. 8. Apparent viscosity versus shear rate curves for Grease No. 4.

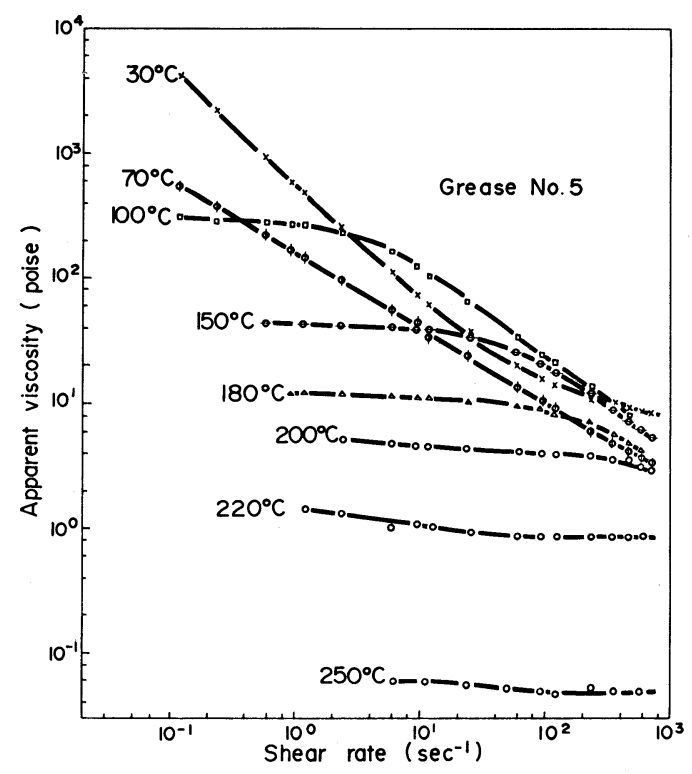

Fig. 9. Apparent viscosity versus shear rate curves for Grease No. 5 . 
$180^{\circ} \mathrm{C}$ 付近では低いせん断速宽領域でニュートン流動を示す。ま た，高いせん断速度領域で比較すると， $30 \sim 200^{\circ} \mathrm{C}$ での見掛け粘 度に大きな差が見られない。

Fig. 10 のカルシウムせっけんグリースは，70C を超えると温 度の上昇之とむに見掛け粘度が著しく低下し， $140^{\circ} \mathrm{C}$ になるとほ 添ニュートン流動を示すようになる。140ㄷ になるとカルシウム せっけんの網目構造が完全に熱的破壊をうけていると予想される。

Fig. 11 のナトリウムテレフタラメートグリースは，高温にな っても見掛け粘度が急激に低下することはなく, 高温でも網目構 造が安定していることが推定される.

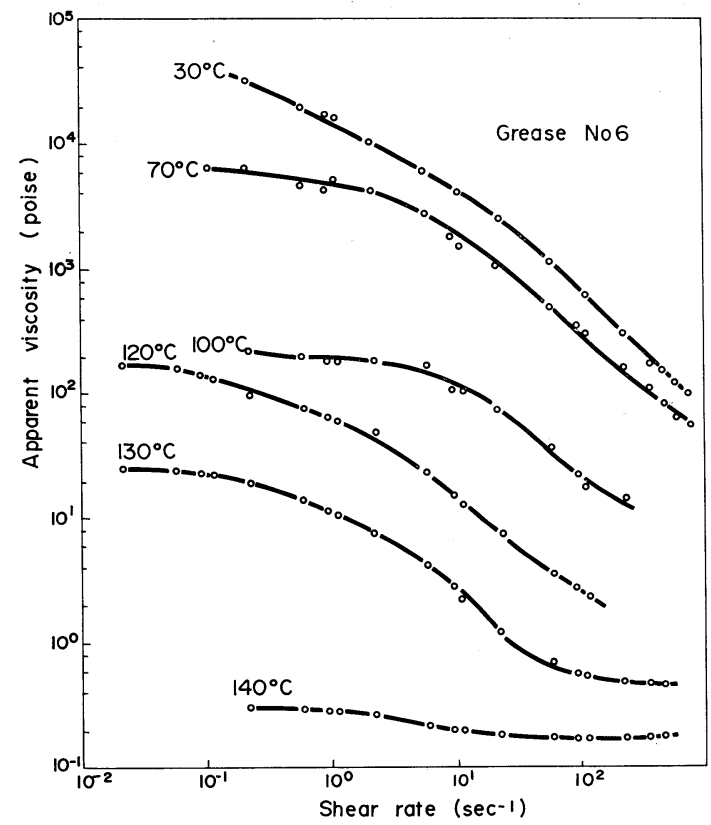

Fig. 10. Apparent viscosity versus shear rate curves for Grease No. 6.

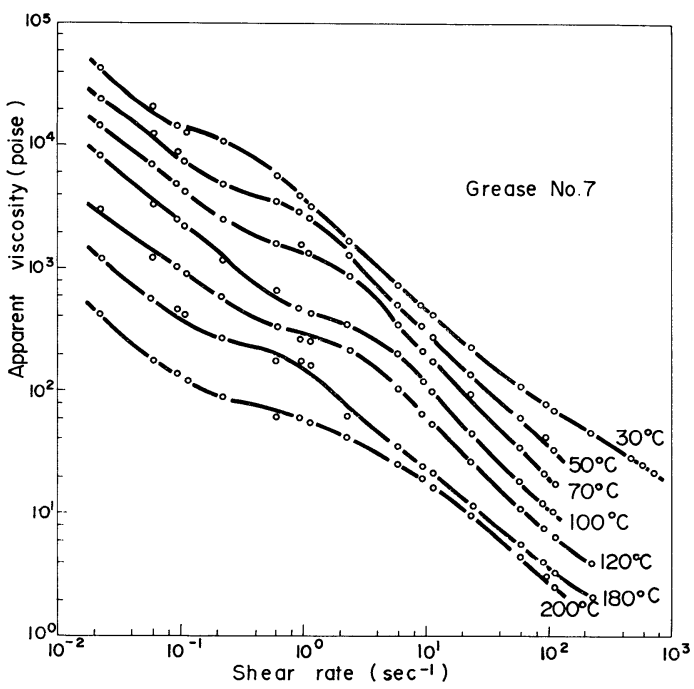

Fig. 11. Apparent viscosity versus shear rate curves for Grease No. 7.

\section{5. 考察}

\section{$5 \cdot 1$ せん断速度と見掛け粘度の関係}

グリースは, 増ちょう剂のつくる三次元の網目構造の間隙に油
がしみ込んだ構造をとっている，せん断をうけると增ちょう阂の 網目構造がせ九断速度に応じて破壊されるので, せん断速度の上 昇とともに見掛け粘度が低下する。

Goodeve' ${ }^{1)}$, Cross $^{2)}$, Williamson ${ }^{3)}$, Thomas') らは, 非ニュート ン流動を示す分散系についてせん断応力による内部構造の破壊 と, 分子熱運動による回復を考慮して見掛け粘度とせん断速度の 関係式を導いている．同様な仮定のあとにグリースの流動挙動を 考察してみる。

分散体の場合, 分散粒子のつくる凝集体の結合点は, せ九断下 において時間的に消滅するほか, 外部から加えられる剪断応力に よって屯変化する，そこで分散体の粘度 クは溶媒の粘度 $\eta_{s}$ 之, 単 位体積当たりの凝集体の結合点の数 $N$ に比例する項の和で与えら れると仮定すると，

$$
\eta=\eta_{s}+\alpha N
$$

ここで いは定数である. 更に，せ九断応力によって結合点の切 れる速紊 $d N_{-} / d t$ は， 女ん断速度 $\dot{S}$ の $n$ 乗に比例すると仮定する と,

$$
\frac{d N_{-}}{d t}=k_{1} N \dot{S}^{n} \quad \text { (2) }
$$

ここで, $k_{1}$ は定数である. また, 結合点が再びできる速度 $d N_{+} /$ $d t$ は, せん断応力によって切れた結合点の数 $\left(N_{0}-N\right)$ に比例す ると仮定すると，再結合速度は式(3)になる。

$$
\frac{d N_{+}}{d t}=k_{2}\left(N_{0}-N\right)
$$

ここで $k_{2}$ は定数， $N_{0}$ は熱平衡のときの結合点の数である．式 (2)，(3)より結合点の数の変化速度は式(4)になる.

$$
\frac{d N}{d t}=\frac{d N_{+}}{d t}-\frac{d N_{-}}{d t}=k_{2}\left(N_{0}-N\right)-k_{1} N \dot{S}^{n}
$$

式(4)より $N$ を求め, 式(1)に代入すると,

$$
\eta=\eta_{s}+\frac{\alpha N_{0}}{1+\left(k_{1} / k_{2}\right) \dot{S}^{n}}+\alpha N_{0}\left(1-\frac{1}{1+k_{1} / k_{2}}\right)^{-\left(k_{2}+k_{1} \dot{s}^{n}\right) t}
$$

ここで, 定常流のときは $t \rightarrow \infty$ に相当し, 式(5) 刀右辺第二項は無 視でき, 式(6)になる。

$$
\eta=\eta_{s}+\frac{K_{1}}{K_{2}+\dot{S}^{n}}
$$

なお，式(6)において $K_{1}=\alpha N_{0} k_{1} / k_{2}, K_{2}=k_{2} / k_{1}$ である.グリー ス中には約 $10 \mathrm{wt} \%$ の増ちょう剂が存在するため，せん断速度が 極めて大きいとき，粘度は $\eta_{\infty}$ (Residual viscosity) になることが 実際的に確かめられているから (7)になる。

$$
\eta_{a}=\eta_{\infty}+\frac{K_{1}}{K_{2}+\dot{S}^{n}} \quad(7)
$$

$\dot{S}$ が高く, $K_{2} \ll \dot{S}^{n}$ のとき，式(7)は式(8)となる.

$$
\eta_{a}=\eta_{\infty}+K_{1} \dot{S}^{-n}
$$

式(8)はグリースの見掛け粘度に関する Siskoの式として広く知ら れている.また， $\dot{S}$ が低くなり $K_{2} \ll \dot{S}^{n}$ のとき，式(7)は $\eta_{a} \doteqdot \eta_{\infty}$ $+K_{1} / K_{2}$ となる.

以上の結果を模式的に示すと, Fig. 12 になる.すなわち, A の領域で第一ニュートン流動, Cで第二ニュートン流動が現れる オストワルド流動になる．Fig. 12 の流動パターンを念頭に各グ リースの流動挙動を考察すると次のようである．グリースの流動 は第一，第二ニュートン流動を有するオストワルド流動曲線にな ることが推定される．室盜付近の測定温度ではかなり広いせん断 


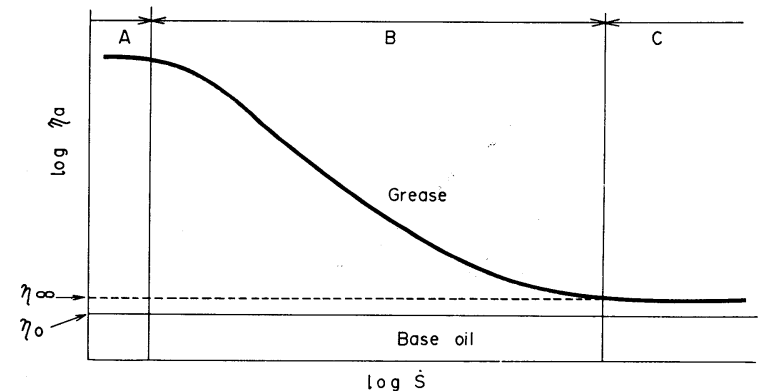

Fig. 12. General form of flow curve of a grease.

速度範囲で測定しないと Fig. 12 の A，C領域まで 網羅する曲線 は得られない。しかし, 測定温度が高くなると狭いせん断速度範 囲が現れることが明らかになった。

\section{$5 \cdot 2$ 温度と見掛け粘度}

高温でのグリース構造の熱安定性を評価するのに, 滴点 (Dropping point, JIS K 2561) が測定されている.グリースはある温 度以上になるとグリースの構造がこわれ，全体が流動的になる か, あるいは基油と増ちょう剤が分離する、滴点はこの転移点に 相当し, 規定のオリフィスからグリースの最初の 1 滴が落下する ときの温度とされている. 乙の方法では, 滴下したあのが基油で あるか増ちょう剂であるか区別し難く，また静的状熊で測定され るため，実際の使用条件に合わないなどの欠点がある，乙のた め, 最近では Brookfield Viscometer による高温での見掛け粘度 の測定が ASTM でも検討され始めている6).

増ちょう剂の網目構造が熱的に破壊されると, 見掛け粘度の低 下の度合が激しくなるので, グリースの耐熱性を見掛け粘度の測 定から比較できる. Fig. 13 には, Fig. 5〜11 の各グリースにつ いてせん断速度 $100 \mathrm{sec}^{-1}$ に扔ける見掛け粘度之温度の関係を示 した。リチウムせっけん, カルシウムせっけんグリースは温度の 上昇とともに見掛け粘度が低下し, 特に前者は $150^{\circ} \mathrm{C}$, 後者は 100 ${ }^{\circ} \mathrm{C}$ 以上になると著しく低下するように思われる。 また, 温度が上

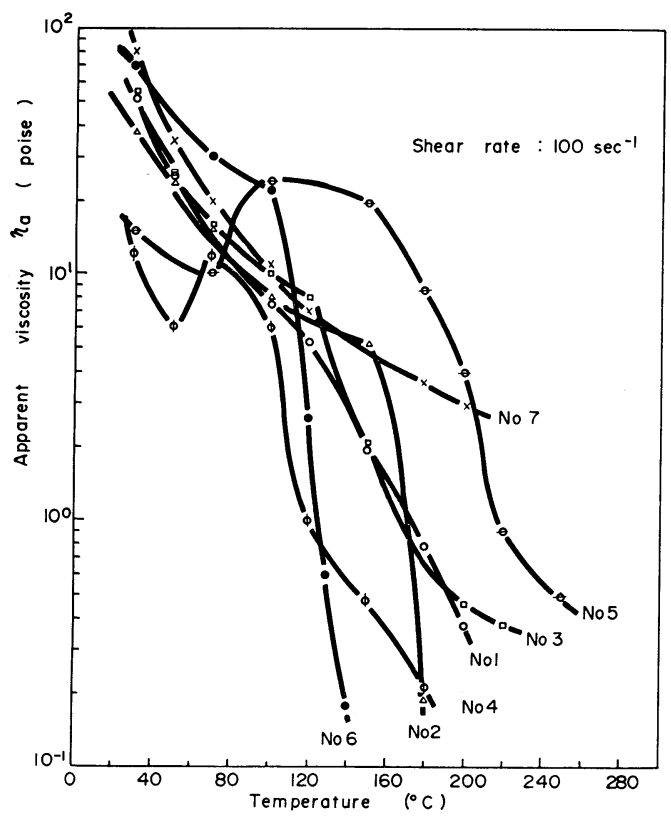

Fig. 13. Apparent viscosity-temprature profiles of various grease samples.
昇するに従い，一般に見掛け粘度が低下するがナトリウムせっけ ん，アルミニウムせっけんグリースはある温度で極大值が現れる ことから，見掛け粘度の増加が始まる温度付近で網目構造に異常 な現象が起こることが推定される。一方，非せっけんであるナト リウムテレフタラメートグリースの見掛け粘度は, 高温になって 屯急激に低下することはなく、金属せっけんグリースに比較して 網目構造が安定であると言える。

\section{$5 \cdot 3$ 温度と相対粘度}

見掛け粘度の温度変化から,グリース構造の熱安定性がほぼ判 定できる。しかし，グリースの見掛け粘度の温度変化の中には， グリース中に 80 〜 $90 \%$ を占める基油の粘度変化屯含まれている. この基油の粘度変化により, 網目構造の変化が見掛け粘度に明瞭 に反映されないことも予想される。そこで基油の粘度変化の影響 を除くため, 本報では見掛け粘度 $\eta_{a}$ と基油粘度 $\eta_{0}$ の比, すなわ ち相対粘度を求め, Fig. 14 亿示した。

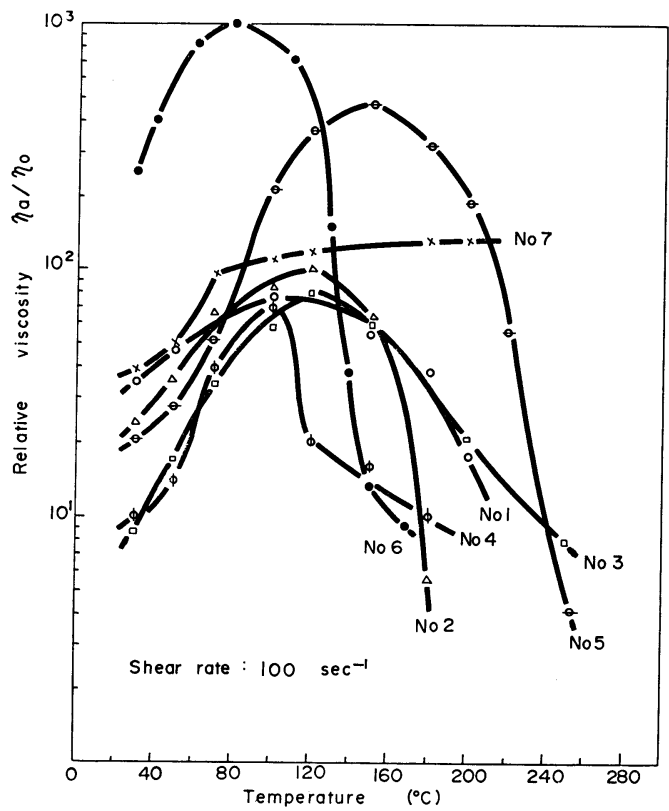

Fig. 14. Relative viscosity-temprature profiles of various grease samples.

見掛け粘度に大きな変化が見られなかったナトリウムテレフタ ラメートグリース(№.7)，あるいは見掛け粘度に極大值が現れた ナトリウムせっけん（№ 4)，アルミニウムせっけんグリース（Na $5 ） に$ 対しては, 相対粘度まで求めても特別な情報は得られなか った。しかし，リチウムせっけん，カルシウムせっけんグリース は，相対粘度を求めると見掛け粘度には見られなかった極大值が 現れた。

温度の上昇とともに相対粘度が上昇するのは, 温度の上昇とと もに増ちょう剂繊維間の結果がゆるみ，より多くの油を繊維間隙 に含むようになる，すなわち，不動化 (immobilize) される油分 が多くなるためであると考えられる，更に，温度が上がると不動 化される油む限界に達し，相対粘度は下がり始める。増ちょう剂 の役目は余分の油を外部に流失するのむ防ぐことにある．相対粘 度が下がり始めると増ちょう剤の油保持能力は低下し，また基油 の粘度もこのような温度では相当低くなっているので流失しやす くなる、したがって，リチウムせっけん，カルシウムせっけんグ 
リースにおいては，それぞれ極大值を示す温度 $120^{\circ} \mathrm{C}, 70^{\circ} \mathrm{C}$ 付近 が使用限界温度と考えられる。

以上のことから, 最近, グリースの構造の熱安定性の評価に見 掛け粘度がとり挙げられる傾向にあるが, 場合によっては相対粘 度も求める必要があることがわかる.

\section{$\mathbf{5}$ ・4 電子顕微鏡による観察}

5・2〜 5・3筑で考察したように，金属せっけんグリースは温度 が高くなると, 増ちょう剤の網目構造がさまざまに変化すること が推察された。さらに本報では, 種々の温度で $600 \mathrm{rpm}$ の回転 (見 掛けのせん断速度, $\left.724 \mathrm{ssc}^{-1}\right)$ を与えた後, 増ちょう剂の網目構 造を電子顕微鏡で観察した。高温でせん断をうけているときの状 態と，せん断を停止し室温に戻したときの状態では，增ちょう剂 の網目構造は必ずしも同一でない。しかし，後者における増ちょ う剤の網目構造の観察から, 前者の状熊において推定される挙動 を一部裹付ける結果が得られた。

各グリースの種々の温度でせん断後の網目構造を Fig. 15〜18 に示した. Fig. 15 には，ステリアリン酸リチウムグリース（№ 1）の観察結果を示した。熱履歴を与えない場合は，良好な網目 構造が形成されている. 高温でせん断を与えると網目構造が破壊 される傾向があり， $180^{\circ} \mathrm{C}$ では繊維同士が接合してしまい，網目 構造が消滅している。乙のグリースの相対粘度が約 $120^{\circ} \mathrm{C}$ 以上に なると低下するようになるのは，乙の温度付近で織織の絡み合い がゆるみ網目構造の破壊が始まるためであると考えられる。また $180^{\circ} \mathrm{C}$ になると相対粘度が著しく低下するのは, 繊維自体の接合

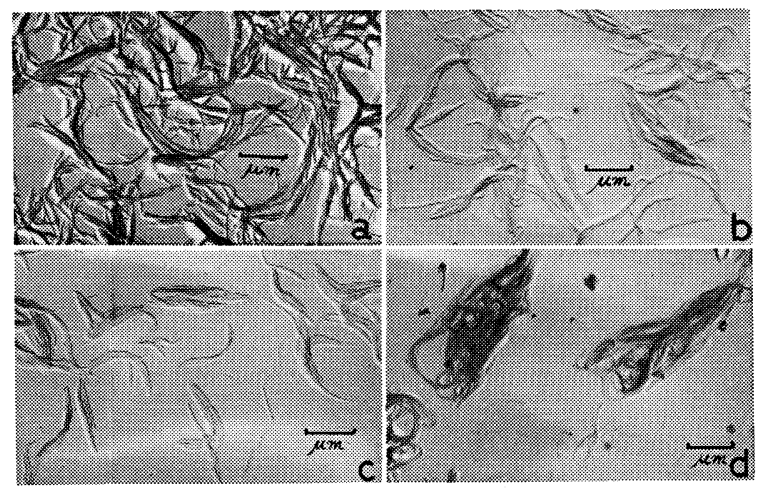

Fig. 15. Electron microphotograph of Li-soap grease (No. 1), after shearing at room temperature (a), $140^{\circ} \mathrm{C}(\mathrm{b}), 160^{\circ} \mathrm{C}(\mathrm{c})$, and $180^{\circ} \mathrm{C}(\mathrm{d})$.

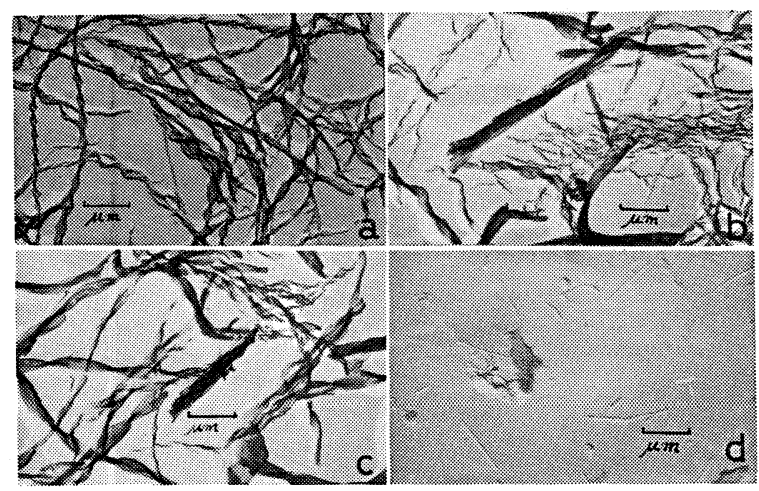

Fig. 16. Flectron microphotograph of Li-soap grease (No. 2), after shearing at room temperature (a), $120^{\circ} \mathrm{C}(\mathrm{b}), 180^{\circ} \mathrm{C}(\mathrm{c})$, and $200^{\circ} \mathrm{C}(\mathrm{d})$.

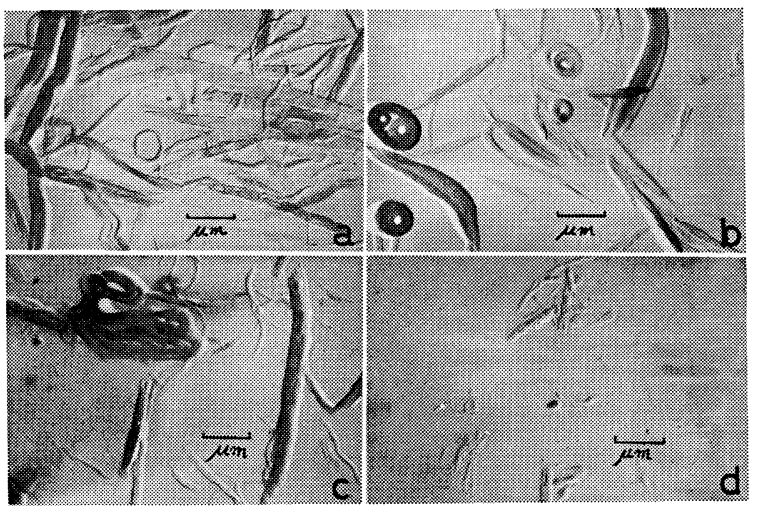

Fig. 17. Electron microphotograph of Na-soap grease (No. 4), after shearing at room temperature (a), $100^{\circ} \mathrm{C}(\mathrm{b}), 150^{\circ} \mathrm{C}(\mathrm{c})$, and $180^{\circ} \mathrm{C}(\mathrm{d})$.

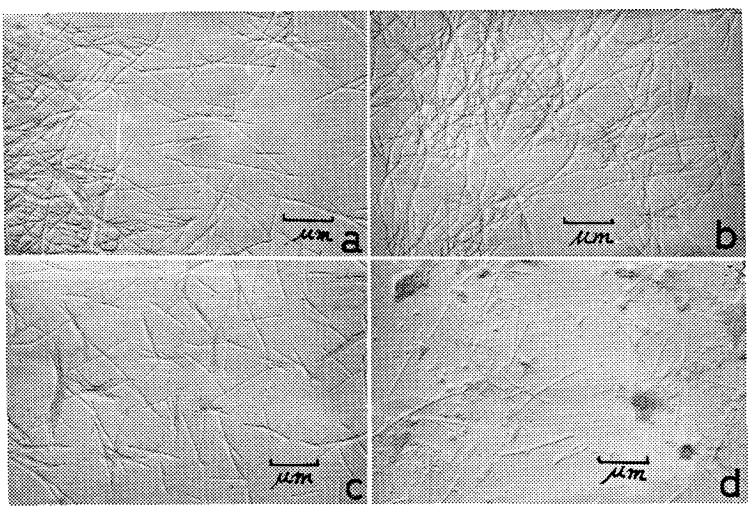

Fig. 18. Electron microphotograph of Ca-soap grease (No. 6), after shearing at room temperature (a), $100^{\circ} \mathrm{C}(\mathrm{b}), 130^{\circ} \mathrm{C}(\mathrm{c})$, and $140^{\circ} \mathrm{C}(\mathrm{d})$.

による網目構造の破壊が考えられる。

Fig. 16 には, 12-ヒドロキシステアリン酸リチウムグリース(No 2) の観察結果を示した。 このグリースは, $120^{\circ} \mathrm{C}$ で熱履歴を与 えると径の太い緘維の成長が見られる. このグリースの相対粘度 は, 約 $120^{\circ} \mathrm{C}$ 以上になると低下する傾向が見られたが, この理由 はこの温度近傍で繊維の径が大きくなるので, 網目間隙に保持で きる油分が減少するためであると推定される．また，200 C でせ ん断を与えた場合, 網目構造は完全に消滅しており, 見掛け粘度 および相対粘度がこの温度付近で著しく低下する理由が説明でき る.

ナトリウムせっけんグリース（№.4）は， $100^{\circ} \mathrm{C}, 150^{\circ} \mathrm{C}, 180$ ${ }^{\circ} \mathrm{C}$ とせん断を与える温度が上昇するにつれて網目構造の破壊が進 んでいる. 見掛け粘度に極大值が見れる理由はFig. 17 からは明 らかでない.

カルシウムせっけんグリース（№.6）は， $130^{\circ} \mathrm{C}$ でせん断を与 えると増ちょう剂の繊維が局部的に破壊され， $140^{\circ} \mathrm{C}$ になると破 壊が更に進行しているととがわかる.

\section{6. 結 言}

高温におけるグリースのレオロジカルな挙動は，增おょう剂の ミセルの絡み合いのほか, 増ちょう剂のミセル自身の変化む起て り極めて複雑であるが, 本報により, 各増ちょう剂に対するおよ その特微が明らかになった。 
グリースのレオロジー的特性は，現在専らグリースを利用する 立場で研究されている．グリースを製造する場合，いったん高温 にした後，様々な熱履歴とかく找を与えながら室温に戻される。 この過程で増ちょう剂ミセルの成長, 網目構造の形成が行われ, このときの操作は後のグリースの物性を決定する重要な因子とな る. 従来, 乙の過程での操作は経験的に行われているが, この過 程にグリースのレオロジー的性質の検討をとり入れることはグリ 一ス製造の際，品質管理の有効な手段となり得ると考えられる. 終わりに, 本研究を進めるに当り東北大学工学部海屋薰教授加
らこん切なる助言を賜ったととに対して深謝する。

\section{参 考 文 献}

1) Goodeve, C.F., Trans. Faraday Soc., 35, 341 (1939).

2) Cross, M.M., J. Colloid Sci., 20, 417 (1965).

3) Williamson, R.V., Ind. Eng. Chem., 21, 1108 (1929).

4) Thomas, G., J. Colloid Sci., 15, 219 (1960).

5) Arvson, M.H., Ind. Eng. Chem., 24, 71 (1932).

6) Harting, G.L., NLGI Spokesman, 38, 13 (1974). 